\title{
Geospatial Analysis Identifies Critical Mineral-Resource Potential in Alaska
}

- This study devised a new geographic information system (GIS)-based method to identify areas that have mineral-resource potential.

- The method identified areas in Alaska that have the potential to contain concentrations of critical minerals.

- Our method provides a valuable template for evaluations of mineralresource potential for large, under-explored regions.

- These results will inform land management decisions, and will also help to guide future mineral exploration activities and scientific investigations.

Alaska consists of more than 663,000 square miles $(1,717,000$ square kilometers) of land-more than a sixth of the total area of the United States - and large tracts of it have not been systematically studied or sampled for mineralresource potential. Many regions of the State are known to have significant mineral-resource potential, and there are currently six operating mines in the State along with numerous active mineral exploration projects. The U.S. Geological Survey (USGS) and the Alaska Division of Geological \& Geophysical Surveys (ADGGS) have developed a new geospatial tool that integrates and analyzes publicly available databases of geologic information and estimates the mineral-resource potential for critical minerals, which was recently used to evaluate Alaska. The results of the analyses highlight areas that have known mineral deposits and also reveal areas that were not previously considered to

\section{Scientific instrument on the Melozitna pluton, Ruby batholith, Alaska. Photograph by Susan Karl, USGS.}

be prospective for these deposit types. These results will inform land management decisions by Federal, State, and private landholders, and will also help guide future exploration activities and scientific investigations in Alaska. For a detailed discussion of the datasets used in the analyses, explanations of the analytical process, and interpreted results of the study, see http://dx.doi.org/10.3133/ ofr20161191.

\section{What are Critical Minerals?}

Critical minerals, sometimes referred to as strategic and critical minerals, are those for which the United States imports more than half of its total supply, and which are largely obtained from nations that cannot be considered reliable trading partners. They are integral to every part of our modern life.

The commodities and mineral deposit groups selected for this study (see table and maps) were identified in a collaborative process that included Federal, State, and academic scientists, as well as State and Federal administrators who have resource-management responsibilities. The deposit groups were selected because they are known or suspected to exist in Alaska and may contain one or more critical minerals.

\section{Examples of Uses of Critical Minerals}

- Rare earth elements, yttrium: recyclable batteries, oil refining, power generators, jet engines, semiconductors, computers, smartphones, night-vision goggles, and permanent magnets such as those used in magnetic resonance imaging (MRI) machines

- Platinum group elements: catalytic converters, toxic emissions scrubbers, electronics, dental applications

- Germanium, gallium: solar cells, infrared optics, light-emitting diodes (LEDs), semiconductors, smartphones

- Uranium, thorium: nuclear power, radio isotopes for medical diagnosis and research

- Tin, indium: architectural glass, flat screens, solar cells, semiconductors, smartphones, lead-free solders, tin-niobium alloys for superconductors

- Tungsten, titanium: highstrength metal alloys, and for tungsten, thermocouples, thermometers, light bulb filaments

- Gold: radiation protection films for spacecraft, dental applications, and jewelry

- Molybdenum, chrome, cobalt, nickel, tantalum, vanadium: superalloys for resistance to wear and corrosion in pipelines, seawater desalination plants, turbines, missiles, and spacecraft 


\section{How is Mineral-Resource Potential Evaluated by this Method?}

This new geospatial method for evaluating mineral-resource potential integrates and analyzes publicly available USGS and ADGGS databases containing multiple kinds of geologic information such as rock type, geochemical composition of rocks and stream sediments, minerals found in streams, geophysical attributes measured from airborne surveys such as magnetic or radiometric properties, and the presence of known mineral occurrences for the specific commodity of interest. Each of these parameters is given a statistically determined score based on data, such as the relative abundance of an appropriate rock type or the amount of an element in a rock or stream sediment, and is tied to a specific subwatershed-the smallest spatial unit defined by the National Hydrography Dataset (https://nhd.usgs. gov/) - by the location where the data were collected. The process uses individual subwatersheds because they provide natural boundaries for rocks and minerals contributed to streams by erosion, and

\section{Results of geographic information system analysis of mineral-resource potential for selected critical minerals in Alaska.}

[Ag, silver; Au, gold; Co, cobalt; $\mathrm{Cr}$, chrome; $\mathrm{Cu}$, copper; $\mathrm{Ga}$, gallium; Ge, germanium; In, indium; Mo, molybdenum; $\mathrm{Nb}$, niobium; $\mathrm{Ni}$, nickel; PGE, platinum group elements; REE, rare earth elements; Sn, tin; Ta, tantalum; Th, thorium, Ti, titanium; $\mathrm{U}$, uranium; $\mathrm{V}$, vanadium; $\mathrm{W}$, tungsten; $\mathrm{Y}$, yttrium; $\mathrm{Zr}$, zirconium ]

\begin{tabular}{llc}
\hline \multicolumn{1}{c}{ Deposit group } & \multicolumn{1}{c}{ Critical minerals } & \multicolumn{1}{c}{$\begin{array}{c}\text { Percentage of high potential } \\
\text { subwatersheds that are newly } \\
\text { recognized (shaded red on maps) }\end{array}$} \\
\hline Alkaline igneous rocks & REE-Th-Y-Nb (U-Zr) & 89 \\
Placer and paleoplacer gold & $\mathrm{Au}$ (PGE-Cr-Sn-W-Ag-Ti) & 41 \\
Mafic-ultramafic rocks & $\mathrm{PGE} \mathrm{(Co-Cr-Ni-Ti-V)}$ & 92 \\
Carbonate-hosted copper & $\mathrm{Cu}(-\mathrm{Co}-\mathrm{Ag}-\mathrm{Ge}-\mathrm{Ga})$ & 68 \\
Sandstone uranium & $\mathrm{U}(\mathrm{V}-\mathrm{Cu})$ & 67 \\
Specialized granites & $\mathrm{Sn}-\mathrm{W}-\mathrm{Mo}-(\mathrm{Ta}-\mathrm{In}-\mathrm{fluorspar})$ & 62 \\
\hline
\end{tabular}

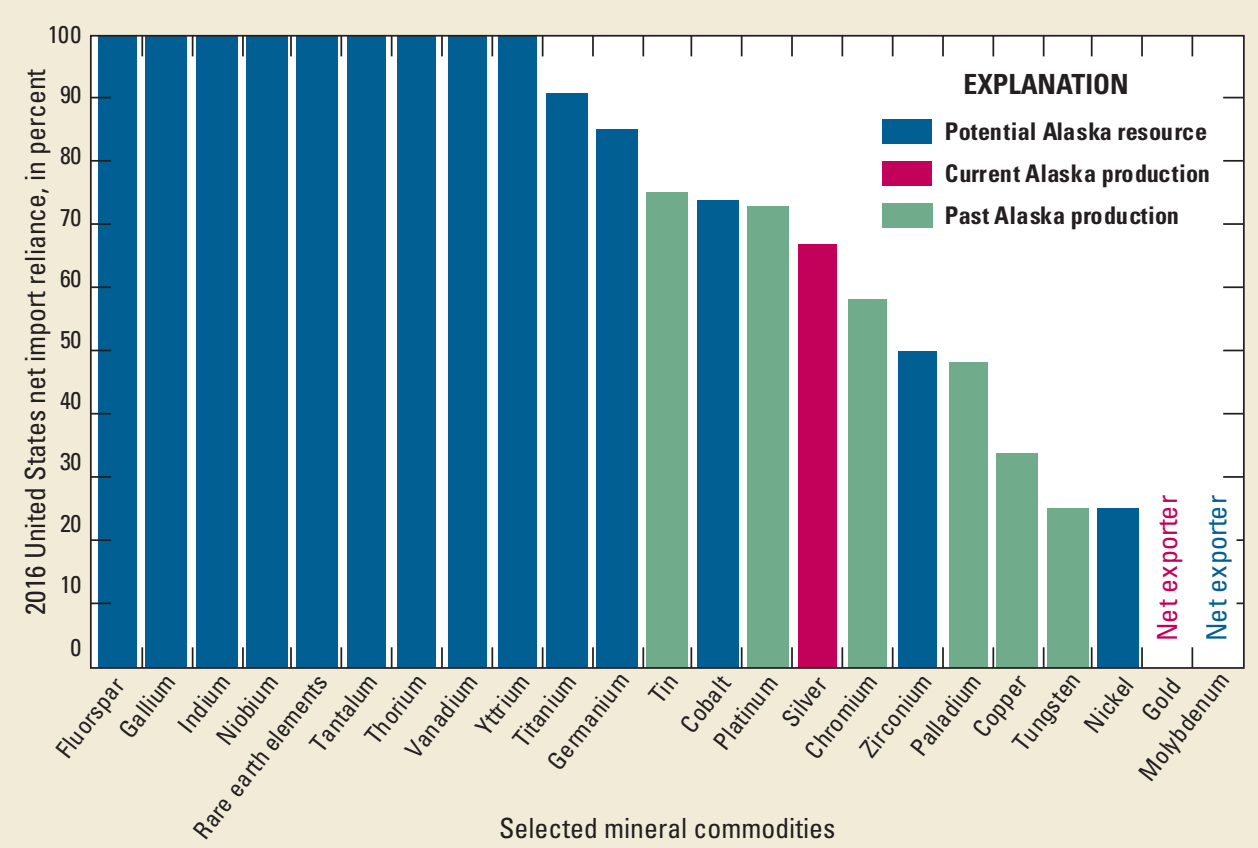

Graph of critical minerals that have been found, or are suspected to be present, in Alaska. Net import reliance (imports minus exports) is expressed as a percentage of domestic consumption. Although gold and molybdenum are net exported minerals, they are important to the economies of the United States and Alaska. Figure prepared by Graham Lederer, U.S. Geological Survey National Minerals Information Center.

thus streams provide the most efficient summary of the geologic composition of a watershed or drainage basin. Each subwatershed is assigned a total score from each data parameter; then the total scores of all the subwatersheds are statistically evaluated Statewide. We use color to show estimated mineral-resource potential: high potential (red), medium potential (yellow), low potential (green), or unknown (gray). The colors are shaded to indicate the relative certainty of the estimate, which is determined by the number of datasets that contributed to the score within each subwatershed: high certainty (dark), medium certainty (medium), or low certainty (light).

\section{What is the Critical Mineral- Resource Potential of Alaska?}

Results of this geospatial analysis indicate that multiple areas in Alaska have mineral-resource potential for each of the six selected critical mineral deposit groups. For example, the Seward Peninsula, east-central Alaska, the western Alaska Range, and southeastern Alaska have knots of red-colored subwatersheds for most of the critical mineral deposit groups addressed in this study (see the table and maps). Using this process, we have identified the potential for critical minerals in new areas such as the northern Brooks Range, and have expanded the area with potential for resources around known mineralized areas like the Seward Peninsula and east-central Alaska.

\section{The Road Ahead}

This study revealed a significant number of previously unidentified areas with high mineral resource potential, indicating that this method has tremendous value for identifying underexplored and understudied areas for any given commodity. Important areas identified by this process are those that have medium to high mineral potential (yellow and red colors on maps) and medium to low certainty (medium to light shaded colors on maps), because additional data could reveal significant potential for an economic concentration of a commodity. The technique also provides a new way to analyze large geospatial datasets in combination, potentially leading to the discovery of new areas for mineral 
$180^{\circ}$ $165^{\circ}$

$150^{\circ}$

$135^{\circ}$

$120^{\circ}$
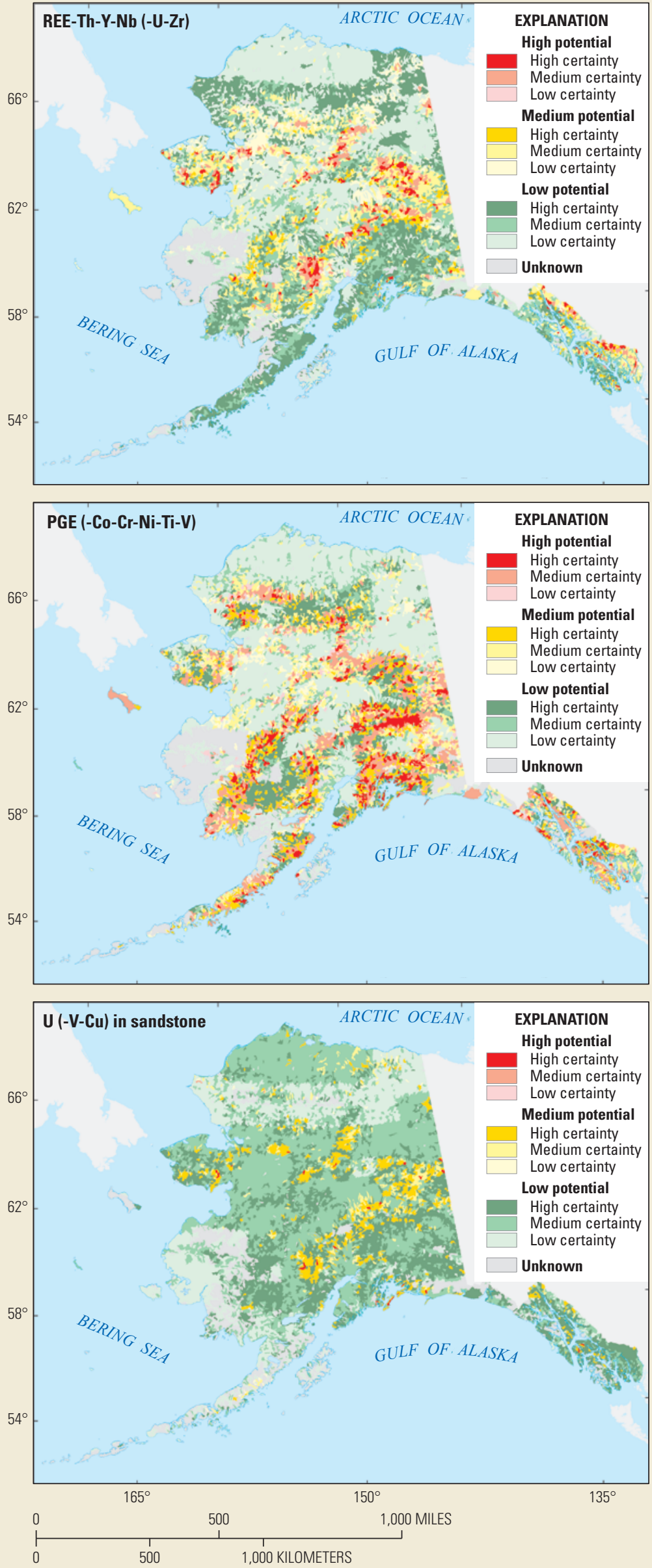

Estimated mineral-resource potential and levels of certainty, indicated by shading of colors, for six selected deposit groups and their associated critical minerals.

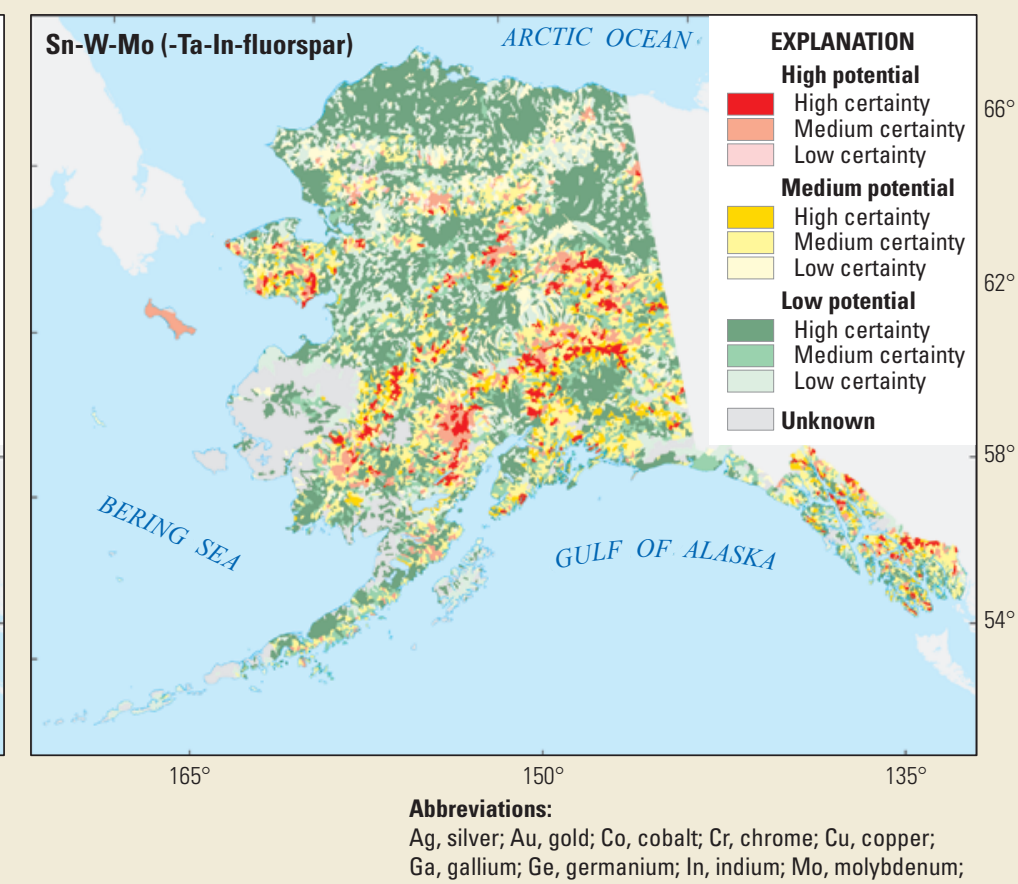

$180^{\circ}$

$165^{\circ}$ $150^{\circ}$ $135^{\circ}$

$120^{\circ}$
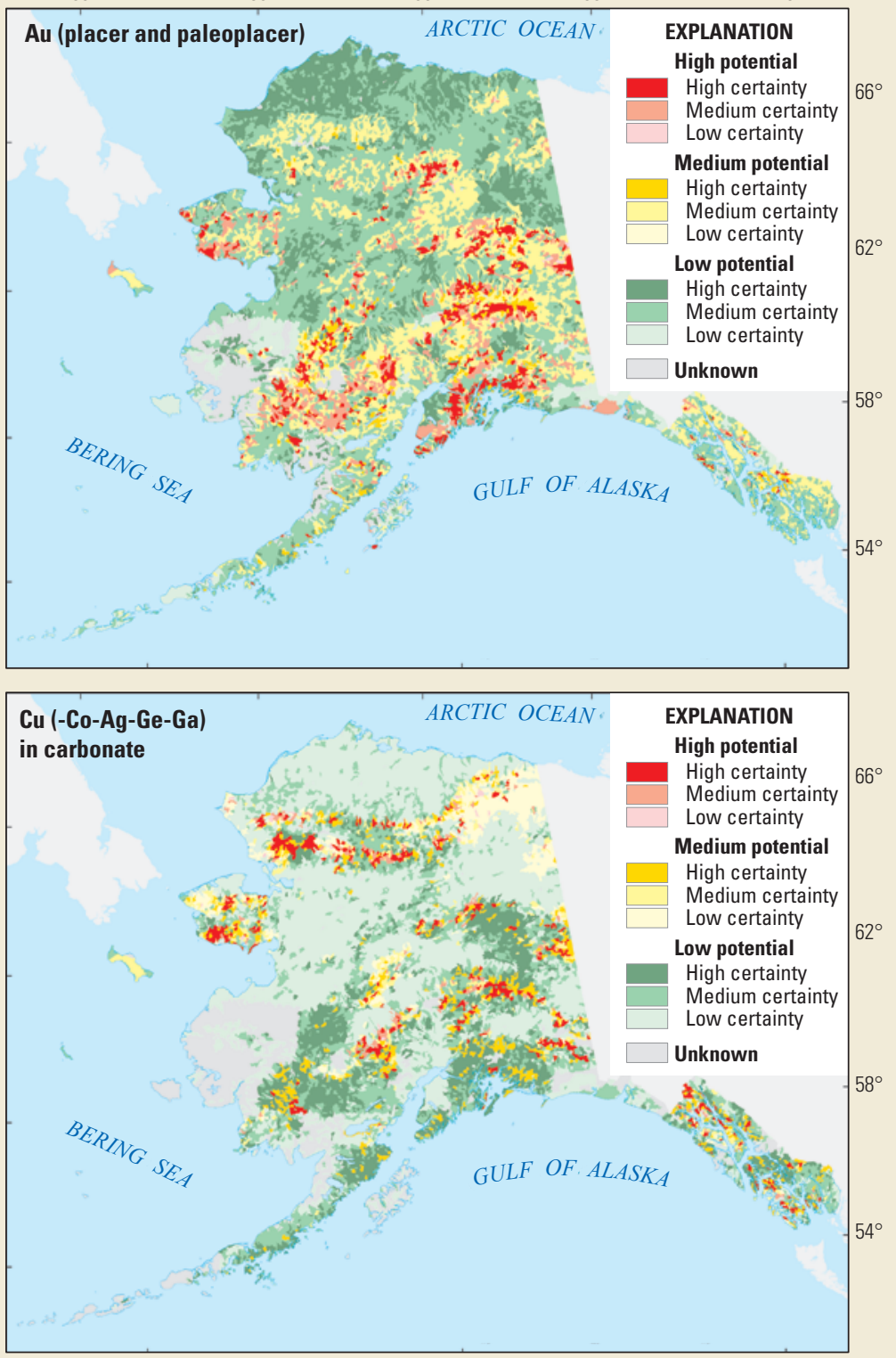

ations:

$\mathrm{Ag}$, silver; $\mathrm{Au}$, gold; $\mathrm{Co}$, cobalt; $\mathrm{Cr}$, chrome; $\mathrm{Cu}$, copper; $\mathrm{Ga}$, gallium; Ge, germanium; In, indium; Mo, molybdenum; $\mathrm{Nb}$, niobium; Ni, nickel; PGE, platinum group elements; $\mathrm{REE}$, rare earth elements; $\mathrm{Sn}$, tin; Ta, tantalum; Th, thorium, $\mathrm{Ti}$, titanium; $\mathrm{U}$, uranium; $\mathrm{V}$, vanadium; $\mathrm{W}$, tungsten; $\mathrm{Y}$, yttrium; Zr, zirconium 
exploration and new insights into the geologic settings and ore-forming processes of mineral deposits.

\section{Read the Full Report}

Karl, S.M., Jones, J.V., III, and Hayes, T.S., eds., 2016, GIS-based identification of areas that have resource potential for critical minerals in six selected groups of deposit types in Alaska: U.S. Geological Survey Open-File Report 2016-1191, 99 p., 5 appendixes, 12 plates, scale 1:10,500,000, http://dx.doi.org/10.3133/ofr20161191.

\section{By Susan Karl and Keith Labay}

Edited by Katherine Jacques and

Claire Landowski

Layout by Suzanne Roberts

\section{For more information, contact:}

\section{Susan Karl}

U.S. Geological Survey

4210 University Drive

Anchorage, AK 99508

https://alaska.usgs.gov/
USGS researchers collecting a soil sample for rare earth elements at the Roy Creek prospect, Alaska. Photograph by Susan Karl, USGS.

Drill rig on Dotson veins at Bokan Mountain rare earth elements deposit. Photograph by Susan Karl, USGS.

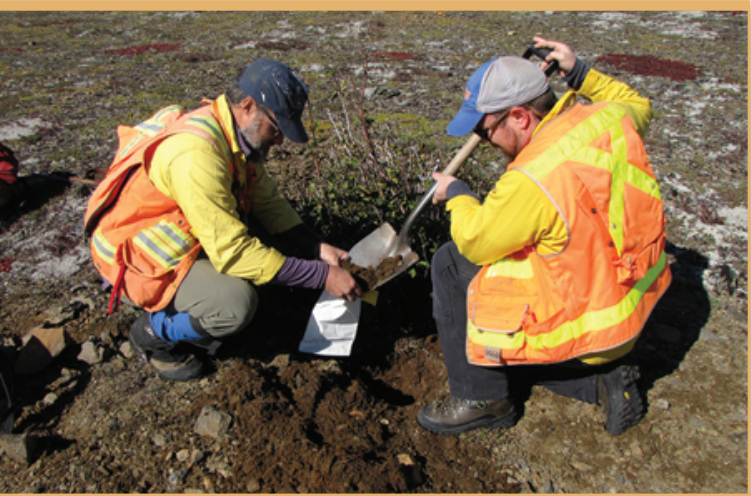

Pictured below: Gold dredge tailings on the Chatanika River north of Fairbanks, Alaska. Photograph by Susan Karl, USGS.

Gold dredge near Nome, Alaska. Photograph by Doug Yager, USGS.
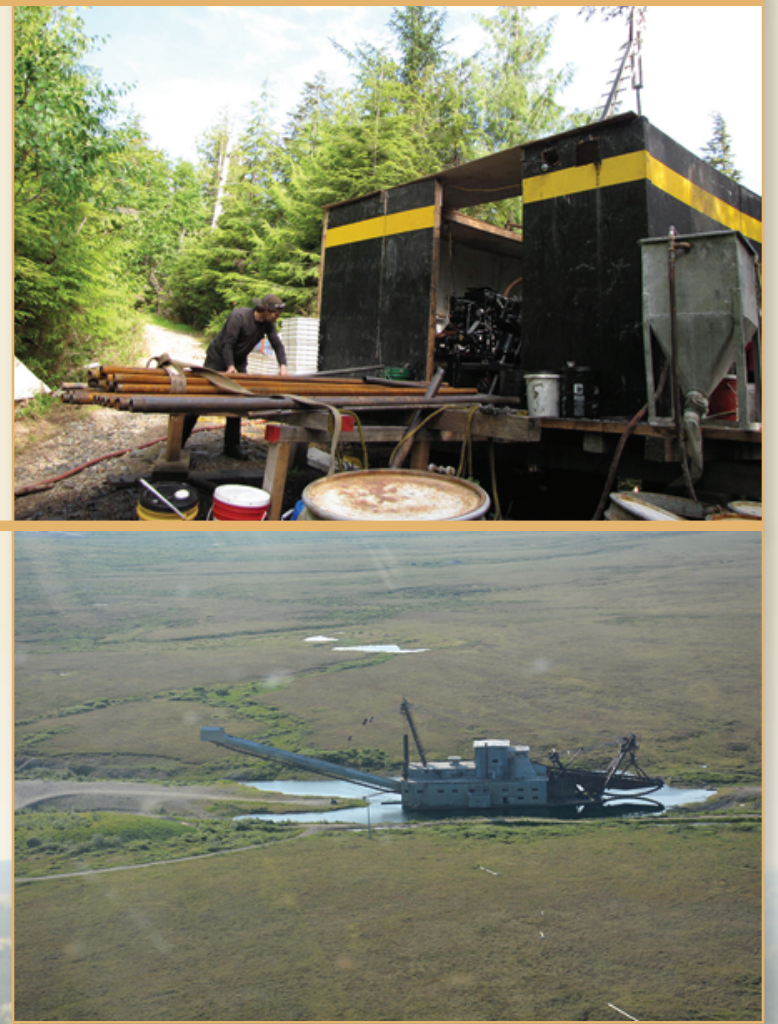